DOI 10.21868/PGnG.2016.2.1.

\title{
The Greek Pension System: Difficult RoAd to Reform
}

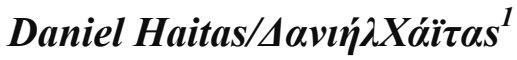

Since the beginning of Greece's financial crisis, the country's administrative structure, financial practices and service provision system have come under heavy scrutiny. The need for external financial assistance naturally meant that the country has experienced a decrease in its autonomy in relation to the running of its own internal affairs and, for the sake of its long term wellbeing and in order to receive necessary funds, had to make painful and drastic changes with regards to the structure and operation of the state. One of the major sources of tension (Hope, 2015) between Greece and its creditors has been the need to reform the country's pension system. There is a general acknowledgement that this system is not sustainable in the long term (Cosgrave, 2015), and that it has been a major contributing factor to Greece's present debt crisis due to its excessively generous nature, rules on early retirement and an ageing demographic. Here we shall analyse the basic past and present features of the Greek pension system, and the various reforms that have been implemented since the beginning of the financial crisis.

The operative, foundational principle of Greece's pension system can be found in the country's constitution (European Commission, 2013), which makes the state responsible for providing social security for all working people, both employed and self-employed. The Greek pension system itself is based on three pillars (Symeonidis, 2013). The first pillar (Pension Funds Online, 2010) operates as a pay-as-you-go system and provides main pensions, secondary (auxiliary) pensions, and lump sum amounts and provident grants. This pillar accounts for $99 \%$ of pensions in Greece, which means that the country is dominated (Adams, 2011) by the state system pillar. The second pillar covers occupational schemes and the third pillar private insurance. In addition to the earnings-based component of the Greek pension system, there is also a minimum level pension(Pension Funds Online, 2010) for those especially deprived and having inadequate means.

Greece's pension system as recently as 2011 was considered to be the weakest in the world (Finke, 2014) in terms of long-term sustainability, and now, even after various reforms, is ranked the 8th lowest in the world (Nardelli, 2015), with no other EU country (Cosgrave, 2015) spending as much on pensions in terms of proportion of GDP, which presently is at

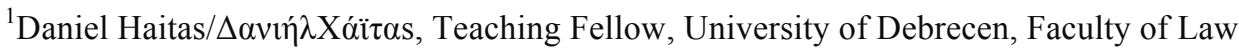


around $17.5 \%$. It is generally acknowledged that Greece's pre-crisis pension system was excessively generous, in fact being one of the most generous in the EU, especially with regards to rules relating to early retirement. For example, in 2010 there existed more than 130 separate pension funds, which, due to various exceptions and loopholes, allowed workers in 580 categories which were considered to be arduous or dangerous to retire in their 50s, with perhaps the most famous example being hairdressers (Davis, 2015) and TV presenters (Crowcroft, 2015). In the year 2006 around over one third (P.W., 2015) of Greek pensioners were classified as working in a dangerous occupation. In terms of payments themselves, in 2009 the average Greek pension was 1,350 euros a month (Crowcroft, 2015), and in 2010 the average Greek pensioner received around $96 \%$ of their original working salary (Davis, 2015), as opposed to, for example, a German pensioner, who receives around half of their working salary. Greek pensioners also formerly received 14 annual pension payments. In addition, according to the basic system, it was necessary only to make 35 years of contributions instead of the 40 years usually required in pension systems in order to be eligible to receive a full pension. There was also a possibility for a person who had made only 15 years of contributions to receive a fairly generous minimum pension, which led to many choosing this option and subsequently seeking to make an income in the black-market. And to illustrate the various irregularities that existed in the system, at the moment Greece's Social Insurance Institute (IKA) is seeking to reclaim around 8 billion euros in false pension claims (Adams, 2011) paid in the past. One notable example that has come to light is the paying out of 1.9 million euros to 1,473 pensioners who, in fact, were dead.

In 2008 the Hellenic Actuarial Authority (HAA) provided projections up until the year 2060 in relation to future expenditure on pensions and came to the conclusion that an enormous $24 \%$ of GDP would need to be spent on pensions by the year 2060. Such unsustainability is strongly connected to what one commentator has referred to as Greece's ,demographic time bomb" (Salourou, 2015). Since the 1980s the country's fertility rates have drastically decreased (Smith, 2013), with one in five Greeks being aged over 65, making Greece the third oldest population in Europe (Davis, 2015), only after Germany and Italy. According to one study (Salourou, 2015), in the year 2030 one in three Greeks will be over 60, and by the year 2050 this age group will comprise $40.8 \%$ of the entire population. It is also predicted that by the year 2060 the population will decrease by 2.5 million inhabitants, going down to 8.6 million.

Despite the very obvious need to reform such a system, political considerations have obstructed changes. One of the major root causes that brought this excessive system into being was the clientelistic nature of 
Greek politics, which used pensions as an electoral strategy in order to ensure support from various sectors of society. Governments have feared making painful changes and going too far in their reforms and thus essentially committing political suicide. This is connected to the fact that in Greece pensions often help to support not just the recipient but their extended families, for example, children and grandchildren. Thus, any changes to the pension system will have far reaching and painful effects for many layers of Greek society. In addition, another important factor that has inhibited reform is that past and present Greek governments have faced major and vehement opposition to implementing changes to the system from the public sector trade unions (Hope, 2015).

With the onset of the financial crisis and Greece's subsequent bailout from the so-called „troika”, the topic of pension reform took centre stage, and has become a major point of acrimony between the country and its various creditors, with the latter taking a tough line on the matter, pushing hard for Greece to implement changes, which, as a result, the country has been compelled to do. A factor, which has helped contribute to the creditors' attitude, is that many of their own citizens have seen the Greek pension system as being overly generous in comparison to their own. For example, around the time of the beginning of the debt crisis, while many other EU citizens were being told that they would have to work for more years than they had originally anticipated, many Greeks enjoyed the benefits of the early retirement rules outlined above. The frustration of other EU citizens (Crowcroft, 2015) was expressed well in 2010 by Swedish Finance Minister Anders Borg, who said, ,Swedes and other taxpayers should not have to pay for Greeks who choose to retire in their 40s".

\begin{tabular}{|c|c|c|c|}
\hline & & Greece & OECD \\
\hline \multirow[t]{2}{*}{$\begin{array}{l}\text { Avarage worker earnings } \\
\text { (AW) }\end{array}$} & EUR & 20100 & 32400 \\
\hline & USD & 26500 & 42700 \\
\hline Public pension spending & $\%$ of GDP & 13.0 & 7.8 \\
\hline \multirow[t]{2}{*}{ Life expectancy } & At birth & 80.7 & 79.9 \\
\hline & At age 65 & 19.2 & 19.1 \\
\hline \multirow[t]{2}{*}{ Population over age 65} & $\%$ of working-age & & \\
\hline & population & 31.7 & 25.5 \\
\hline
\end{tabular}

It must be acknowledged that efforts to bring about reform to the Greek pension system have borne fruit, with substantial changes having been made since the onset of the crisis and the implementation of the bailout packages. For example, the 130 funds that previously provided pension coverage have been merged into just 6 (Pension Funds Online, 2010) different schemes. Pensions over 2000 euros a month were cut by $40 \%$, and those worth less 
than 1000 euros a month were cut by $14 \%$ (Petroff, 2015). In addition, now a Greek pensioner can only receive $65 \%$ of their original working salary. Since 2010 the average pension has been reduced to around 700 euros a month, which is a reduction of around $44-48 \%$, and now around $45 \%$ of pensioners receive less than 665 euros a month, which is in fact below the official poverty line (Hope, 2015). The official age for receiving pensions was raised (OECD, 2013) to 67 for both men and women respectively. In addition, the 14 annual pension payments were decreased to 12 . The list of arduous professions has also been reduced from 580 to around 100, and is now restricted to truly dangerous professions. And despite the Syriza government's initial resistance (Cosgrave, 2015) to any further pension cuts, one of the conditions of Greece receiving funds under the new bailout deal worked out with its creditors is that there be a „comprehensive pension reform program" (Crowcroft, 2015). In response to this demand, a new bill was passed which seeks to incrementally raise the retirement age (Koutantou\&Papadimas, 2015) and brings about a cut to pensions of 10\% for those who have retired before reaching the age of 67 .

Most recently, in June of this year around 148, 000 pensioners had their pensions cut by half (Chrysopoulos, 2016). These were receiving the supplementary solidarity pension (EKAS), and after the latest round of government reforms these pensioners were no longer eligible to receive this benefit (Chrysopoulos, 2016). In the future this measure shall also be applied to those who receive a higher pension income, and so ultimately these cuts shall affect approximately 250, 000 Greek citizens (Chrysopoulos, 2016). In addition, around 284, 000 pensioners receiving a dividend from the Civil Servants Share Fund shall see a loss in come, the majority of which will experience a slash in their payments of $44 \%$ (Chrysopoulos, 2016).

Bearing in mind these painful adjustments that Greek society has had to make and live with, it is also worth mentioning the difficulties that Greek pensioners experienced this year during the standoff between the Syriza government and the country's creditors. When a referendum was called last summer by Prime Minister Alexis Tsipras in order to decide whether Greece should accept creditors' bailout conditions, capital controls were implemented, limiting the amount of cash that Greeks could withdraw from their banks. For pensioners, this was 120 euros a week (BBC News, 2015). The difficulty was compounded by the fact that many older Greeks do not own debit or credit cards, which meant lining up for hours to withdraw their money, with images being broadcasted all around the world showing crowds of pensioners outside of banks, experiencing great stress, and at times, emotional breakdown. 
There have been very real and painful efforts in order to reform the Greek pension system and to correct its past errors and excesses. However, it must be kept in mind that, despite the unsustainable nature of the system and the very vital need to reform, the cutting of pensions has helped to contribute to the humanitarian crisis Greece is now facing, and further cuts demanded by creditors will make an already dire situation even worse. In human terms, the great difficulty in making the necessary adjustments is that the system acts as a vital social welfare provider for individuals and often also for their loved ones. Thus, Greece's pension system can be said to be an example of the dependence caused by a policy which in its very essence was misguided, yet becomes so much an intrinsic, substantial and characteristic part of a society over time that when necessary reforms must be made, the suffering and disruption to society becomes immense, and for some, often unbearable.

List of References:

Adams, D. (2011). A Greek tragedy. European Pensions. November/December 2011

BBC News (2015). Greece debt crisis: The cost to pensioners. BBC News. July 3, 2015

Chrysopoulos, P. (2016). Low Pensions Slashed by $48 \%$ for 148,000 Recipients in Greece. Greek News Reporter. Jun 30, 2016

Cosgrave, J. (2015). Why Greece's pensions are key to the debt deadlock. CNBC. June 18, 2015.

Crowcroft, O. (2015). Greek debt crisis: Greece takes axe to bloated pension system with retirement age hike to 67. IBT. July 10, 2015

Davis, O. (2015). Greek Debt Crisis: Greece's Pension System Was Once A Bloated Mess, Now It's A Crucial Lifeline For Struggling Families. IBT. August 7, 2015

European Commission (2013). Your social security rights in Greece. June 2, 2013

Finke, R. (ed.) (2014). Pension Sustainability Index, International Pension Papers, $1 / 2014$

Hope, K. (2015). Q\&A: Greek pensions - deal or no deal. Europe. June 4, 2015.

Koutantou, A - Papadimas, L. (2015). Greek experts call for pension reform amid protests. Reuters. October 15, 2015

Nardelli, A. (2015). Unsustainable futures? The Greek pensions dilemma explained. The Guardian. June 15, 2015

OECD (2013). Pensions at a glance 2013: country profiles - Greece. 2013

P.W. (2015). Greek pensions, Why they are a flashpoint. June 18, 2015

Pension Funds Online (2010). Greece. 2010 
PUBLIC GOODS \& GOVERNANCE, 2016. VOL. 1. No. 2

Petroff, A. (2015). How to fix Greece's big pension problem. CNN Money. July 15,2015

Salourou, R. (2015). Greece's demographic time bomb is about to go off. Ekathimerini. October 3, 2015

Smith, H. (2013). Greece's birth-rate falls as austerity measures hit healthcare. The Guardian. September 18, 2013

Symeonidis, G. (2013) The Greek Pension Reform Strategy 2010-2013. Steering away from the tip or the iceberg? Hellenic Actuarial Authority. November 2013 